\title{
Comment on "Pooled analysis of Xpert bladder cancer based on the 5 mRNAs for rapid diagnosis of bladder carcinoma"
}

\author{
Gopal Sharma@
}

\begin{abstract}
This article is a commentary on an article published in World Journal of Surgical Oncology by Liu et al. With this study, authors evaluated diagnostic accuracy of Xpert bladder cancer monitor in detecting recurrences. With this article, we highlight the strengths and limitations of the study.
\end{abstract}

Keywords: Bladder cancer, NMIBC, Xpert BC

Sir,

I read an article published by Liu et al. [1] in the February edition of World Journal of Surgical Oncology. I read this article with keen interest and would extend my best wishes to the study authors. This study aimed to "reviewing the performance of Xpert $\mathrm{BC}$ in the follow-up of bladder cancer and evaluating the role of Xpert $\mathrm{BC}$ in detecting NMIBC recurrence in the round". The study has been well performed in my opinion; however there are certain issues which I would like to highlight.

1. I have reservations over inclusion of study by Valenberg et al. [2], as this study tested accuracy of Xpert bladder cancer (BC) in patients who presented with hematuria. Hence still study does not meet the primary aim of this study, which was to detect diagnostic accuracy of Xpert BC in patients with bladder cancer on follow-up.

2. Study authors have pooled overall data of study by Wallace et al. [3] that included patients with both known case of bladder cancers (on surveillance) and

This comment refers to the article available at https://doi.org/10.1186/ s12957-021-02154-0.

Correspondence: gopal.26669192@gmail.com

Department of Urology, PGIMER, Chandigarh 160012, India patients who presented with hematuria. Thus, in my opinion separate data for patients with $\mathrm{BC}$ on surveillance should be extracted and reanalyzed.

3. Lastly, use of different gold standard techniques by different studies is yet another limitation of this study which needs to be highlighted. Subgroup analysis according to the gold standard modality could also be performed.

To conclude, the results of this study need to interpret with caution due to abovementioned limitations and if possible needs revision for above mentioned points as they have potential to change the overall results.

\section{Acknowledgements}

None

Author's contributions

G Sharma - Protocol development, data collection and management, data analysis, and manuscript writing. The author(s) read and approved the final manuscript.

Funding

None

Availability of data and materials

All data generated or analyzed during this study are included in this published article. 


\section{Declarations}

Ethics approval and consent to participate

Not applicable

\section{Consent for publication}

Not applicable

\section{Competing interests}

The author declares no competing interests.

Received: 16 April 2021 Accepted: 2 July 2021

Published online: 11 August 2021

\section{References}

1. Liu Y-L, Wang X-L, Yang X-H, Wu X-H, He G-X, Xie L-M, et al. Pooled analysis of Xpert Bladder Cancer based on the 5 mRNAs for rapid diagnosis of bladder carcinoma. World Journal of Surgical Oncology. 2021;19(1):42. https://doi.org/10.1186/s12957-021-02154-0.

2. Valenberg F, Hiar AM, Wallace E, Bridge JA, Mayne DJ, Beqaj S, et al. Validation of an mRNA-based urine test for the detection of bladder cancer in patients with haematuria. European Urology Oncology. 2020.

3. Wallace E, Higuchi R, Satya M, McCann L, Sin MLY, Bridge JA. Development of a 90-minute integrated noninvasive urinary assay for bladder cancer detection. J Urol. 2018;199(3):655-62. https://doi.org/10.1016/j.juro.2017. 09.141 .

\section{Publisher's Note}

Springer Nature remains neutral with regard to jurisdictional claims in published maps and institutional affiliations.

Ready to submit your research? Choose BMC and benefit from:
- fast, convenient online submission
- thorough peer review by experienced researchers in your field
- rapid publication on acceptance
- support for research data, including large and complex data types
- gold Open Access which fosters wider collaboration and increased citations
- maximum visibility for your research: over 100M website views per year
At BMC, research is always in progress.
Learn more biomedcentral.com/submissions

